Jurnal KONTEKSTUAL

Volume 01, No. 1, Agustus 2019, pp. 45-53

\title{
PENGARUH MODEL COOPERATIVE TIPE TGT TERHADAP KEMAMPUAN BERPIKIR KRITIS MATEMATIKA SISWA KELAS IV
}

\author{
Novi Yuliyanti ${ }^{1}$, Diah Sunarsih*2 \\ ${ }^{1,2}$ Prodi Pendidikan Guru Sekolah Dasar, Fakultas Keguruan dan Ilmu Pendidikan, \\ Universitas Muhadi Setiabudi Brebes, Indonesia \\ Email corresponden: *2diahsunarsih@umus.ac.id
}

\begin{abstract}
Abstrak
Penelitian ini dilatarbelakangi masih rendahnya kemampuan berpikir kritis siswa kelas IV terhadap pelajaran matematika. Hal ini ditunjukan dengan hasil ulangan harian matematika hanya memperoleh ketuntasan klasikal 43,80\%. Berkaitan dengan permasalahan tersebut, perlu adanya proses perbaikan dalam proses pembelajaran matematika di sekolah dasar, dimana model pembelajaran cooperative tipe TGT dianggap paling tepat dalam pembeajaran matematika karena menciptakan suasana belajar yang menyenangkan. Penelitian ini bertujuan untuk mengetahui perbedaan kemampuan berpikir kritis antara siswa yang diberikan model pembelajaran Cooperative Tipe TGT dengan siswa yang diberi model pembelajaran konvensional pada pembelajaran matematika siswa kelas IV SDN 1 Dukuhtengah. Penelitian ini menggunakan metode penelitian Quasi Experimental dengan desain penelitian Nonequivalent Control Group Design. Subjek populasi dalam penelitian ini adalah seluruh siswa kelas IV SDN 1 Dukuhtengah yang berjumlah 60 siswa. Teknik pengumpulan data dengan menggunakan instrument soal tes berbentuk Essay yang terdiri dari 10 soal yang valid dan reliabel. Pengujian hipotesis potest dari hasil uji t diperoleh $t_{\text {hitung }}$ $2,53>t_{\text {tabel }} 2,08$, maka dapat disimpulakan bahwa terdapat berbedaan kemampuan berpikir kritis yang signifikan antara siswa yang menggunakan model pembelajaran Cooperative tipe TGT dengan siswa yang menggunakan model pembelajaran konvensional.
\end{abstract}

Kata Kunci: Cooperative Tipe TGT, Kemampuan Berpikir Kritis

\begin{abstract}
This research is motivated by the still low level of critical thinking skills of IV grade students in mathematics. This is indicated by the results of daily mathematical tests only get a classical completeness of $43.80 \%$. In connection with these problems, there needs to be a process of improvement in the process of learning mathematics in elementary schools, where the TGT cooperative learning model is considered the most appropriate in mathematics learning because it creates a pleasant learning atmosphere. This study aims to determine the differences in critical thinking skills between students who are given the TGT Cooperative learning model and students who are given conventional learning models in mathematics learning for students in grade IV SDN 1 Dukuhtengah. This study uses the Quasi Experimental research method with the Nonequivalent Control Group Design research design. The population subjects in this study were all students of class IV SDN 1 Dukuhtengah, totaling 60 students. Data collection techniques using the test instrument in the form of Essays consisting of 10 valid and reliable questions. Potest hypothesis testing from the t test results obtained $t$-count $2.53>t$ table 2.08 , it can be concluded that there are significant critical thinking skills differences between students who use the TGT type Cooperative learning model with students who use conventional learning models.
\end{abstract}

Keywords: Cooperative Type TGT, Critical Thinking Ability

Submitted: 2019, Accepted: 2019, Published: Agustus 2019

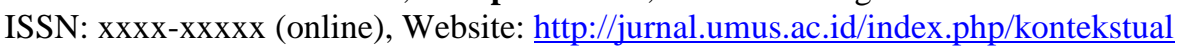


Jurnal KONTEKSTUAL

Volume 01, No. 1, Agustus 2019, pp. 45-53

\section{PENDAHULUAN}

Pendidikan merupakan salah satu aspek yang dibutuhkan manusia dalam kehidupannya. Pendidikan menciptakan sumber daya manusia yang berkualitas dan dapat berguna dalam membangun bangsa kea rah yang lebih baik. Pendidikan merupakan suatu keharusan bagi manusia karena pada hakikatnya manusia lahir dalam keadaan tidak berdaya, tidak langsung dapat erdiri sendiri, dan dapat emelihara dirinya sendiri. Sehingga masyarakat semakin menyadari akan pentingnya pendidikan untuk bersaing meraih kesempatan dalam berbagai bidang, oleh kerana itu melalui pendidikan sumber daya manusia dapat ditingkatkan. Sebagaimana yang tercantu dalam UU. RI No. 20 Tahun 2003 tentang Sistem Pendidikan Nasional [1].

Sesuai dengan tujuan pendidikan nasional bahwa pendidikan sekolah dasar tidak hanya membekali para siswa mempunyai kemampuan membaca, menulis, dan menghitung. Melainkan juga untuk mengembangkan keterampilan dan potensi siswa baik mental mapun spiritual. Upaya yang dilakukan agar tercapainya tujuan pendidikan sesuai yang diharapkan maka baik siswa maupun guru perlu memliki sikap, kemauan, kemampuan dan ketrampilan yang mendukung proses belajar mengajar. Dengan demikian, siswa dan guru mempunyai keterkaitan yang tidak dapat dipisahkan.

Pendidikan merupakan unsur terpenting dalam mewujudkan kemajuan suatu bangsa, karena maju mundurnya suatu bangsa pada masa kini atau masa mendatang akan sangat ditentukan oleh pendidikan. Pendidikan yang bermutu merupakan hal yang sangat penting dalam kemajuan suatu bangsa. Meningkatkan mutu pendidikan merupakan cara untuk menjadikan pendidikan di Indonesia menjadi lebih baik dan berkualitas. Hal ini menuntut pemerintah untuk menciptakan sumber daya manusia yang berkualitas tinggi dan memiliki kemampuan matematika.

Salah satu cara untuk membentuk sumber daya manusia yang berkualitas dapat dilakukan melalui pendidikan matematika. Pendidikan matematika yang diberikan sejak masih di bangku sekolah dasar mempunyai potensi yang sangat besar dan potensi yang sangat strategis dalam menyiapkan SDM yang berkualitas untuk menghadapi era industri dan globalisasi. Pendidikan matematika sejak di bangku sekolah dasar diharapkan dapat digunakan untuk menunjang pembelajaran matematika di bangsu sekolah mnengah pertama atau sederajat atau sebagai jembatan untuk pendidikan di bangsu sekolah menengah atas atau sederajat.

Pelajaran matematika merupakan pelajaran yang dianggap sulit dan tidak mudah untuk dipelajari, salah satu hambatan dalam pembelajaran matematika adalah siswa kurang tertarik dalam pelajaran matematika. Hal ini dapat berpengaruh pada proses berpikir kritis siswa dalam pelajaran matematika. Hal ini berarti perlu adanya variasi dalam proses pembelajaran matematika, seperti halnya dalam pemilihan model pembelajaran. Realita di dunia pendidikan saat ini, kemampuan siswa dalam berpikir kritis dan sistematis kurang diasah. Mata pelajaran matematika khusunya, siswa hanya menghafalkan konsep suatu rumus, sementara kemampuan siswa dalam berpikir dan memecahkan masalah yang dapat dihubungkan dalam kehidupan sehari-hari kurang terasah. Sehingga ketika berhadapan dengan masalah yang ada dalam kehidupan sehari-hari berkaitan dengan materi yang telah diajarkan, siswa 
Jurnal KONTEKSTUAL, Volume 1, No. 01, Agustus 2019, pp. 45-53

tidak dapat mengapliksikannya dengan baik.

Kurang adanya interaksi antara guru dan siswa dalam proses pembelajaran merupakan salah satu faktor yang menyebabkan masalah tersebut terjadi. Kegiatan guru dalam proses pembelajaran hanya menerapkan dan memberikan contoh soal kemudia meminta siswa mengerjakan soal yang terdapat dalam lembar tersebut. Hanya terjadi komunikasi satu arah dalam pembelajaran tersebut, yang mengakibatkan siswa terlalu terbiasa menerima sesuatu apapun yang diberikan tanpa berusaha berpikir dan mempertanyakan tentang kejelasannya. Selain itu, anggapan negative siswa tentang matematika diduga juga berpengaruh terhadap kemampuan berpikir kritis siswa. Dimana siswa sudah terlebih dahulu menyerah terhadap soalsoal yang menurutnya berbeda dengan apa yang telah dijelaskan oleh guru. Telebih soal-soal yang mengerahkan kemampuan berpikir secara lebih mendalam. Faktor lainnya yaitu minat belajar siswa rendah sehingga berpengaruh terhadap berpikir kritis siswa.

Dari pendapat di atas, cooperative tipe TGT merupakan model pembelajaran yang baik dalam meningkatkan kemampuan berpikir kritis siswa dalam kegiatan pembelajaran. Selain itu dengan penerapan yang baik maka akan berpengaruh baik terhadap kemampuan berpikir kritis siswa. Berpikir kritis adalah berpikir secara beralasan dan reflektif dengan menekankan pembuatan keputusan tentang apa yang harus dipercayai atau dilakukan[2]. Berdasarkan pemaparan tersebut peneliti perlu melakukan kajian ilmiah, mengenai pengaruh model cooperative tipe TGT terhadap kekampuan berpikir kritis siswa kelas IV SDN 1 Dukuhtengah kabupaten Brebes.

\section{KAJIAN TEORI}

Pembelajaran matematika harus mulai diubah, bukan lagi mengajar dengan cara memberi tahu atau mendemonstrasi. Campuran dari metodologi pembelajaran dianjurkan agar mampu memasukan kerja kelompok dan individual serta pembelajaran secara langsung. Beberapa model pembelajaran dapat berpengaruh besar terhadap tujuan-tujuan spesifik. Pada dasarnya hal ini berarti bahwa siswa sebenarnya dapat belajar materi dua atau tiga kali lebih cepat ketika siswa menggunakan model pembelajaran yang berkesan dan menyenangkan[3].

Pembelajaran

kooperatif kelompok kecil menawarkan kesempatan kepada semua anggota untuk bisa berhasil dalam matematika. Interaksi kelompok ditujukan untuk membantu semua anggota mempelajari konsep dan strategi pemecahan masalah. Masalah-masalah matematika disesuaikan dengan diskusi kelompok kooperatif karena mempunyai solusi yang bisa ditunjukan secara objektif[4]. Lebih lanjut dijelaskan bahwa para siswa bisa saling mengajukan persuasi dengan menggunakan argumentargumen logis mereka.

Salah satu tipe model pembelajaran cooperative yang mudah diterapkan adalah teams games tournament. Dilihat dari salah satu tahapan TGT yaitu permainan akan membuat siswa tidak jenuh dan bosan terhadap pelajaran matematika bahkan mungkin akan menyukai pembelajaran matematika. Secara umum TGT menggunakan turnamen akademik, dan menggunakan kis-kuis serta sistem skor kemajuan individu, dimana para siswa berlomba 
sebagai wakil tim mereka dengan anggota tim lain yang kinerja[6].

Penggunaan model pembelajaran cooperative tipe TGT diharapkan dapat permasalahan-permasalahan yang diperoleh pada saat pembelajaran. Cooperative learning merupakan kegiatan belajar siswa yang dilakukan dengan cara berkelompok, dan individu memiliki tanggng jawab pada kelompoknya[6]. Model pembelajaran kelompok adalah rangkaian kegiatan belajar yang telah ditumuskan. Belajar dengan kelompok dapat meningkatkan pengetahuan dan pemahaman siswa dimana siswa dapat pertukar pikiran dan pendapat yang dimana dapat memecahkan masalahmasalah yang belum terpecahkan sehingga tujua pembelajaran dapat tercapai[7]

Model TGT adalah suatu model pembelajaran yang digunaan dalam proses belajar mengajar yang diawali dengan pemberian materi kepada siswa dan setelah itu diakhiri dengan pemberian pertanyaan dalam bentuk permainan tournament yang terdiri dari beberapa kelompok dan dalam satu kelompok terdiri dari 5 sampai 6 orang siswa. Dari pendapat beberapa ahli di atas, dapat disimpulkan bahwa TGT merupakan model pembelajaran yang baik dalam meningkatkan kegiatan belajar.

Berpikir kritis adalah proses disiplin secara intelektual dimana seseorang secara akif dan terampil memahami, mengaplikasi, menganalisis, mensintesakan, dan mengevaluasi berbagai informasi yang dia kumpulkan atau yang dia ambil dari pengalaman, dari pengamatan, dari refleksi, dari penalaran atau dari komunikasi yang dilakukan[8]. Dari beberapa pendapat tersebut dapat disimpulkan bahwa berpikir kritis adalah berpikir atas segala sesuatu yang dialami oleh diri sendiri, yang kemudia diproses lebih mendalam lalu disimpulkan.

Lebih lanjut berpikir kritis adalah kemampuan untuk menganalisis fakta, mencetuskan dan menata gagasan, mempertahankan pendapat, membuat perbandingan, menarik kesimpulan, mengevaluasi argument dan memecahkan masalah[9]. Berdasarkan beberapa pendapat tersebut, maka dapat disimpulkan bahwa berpikir kritis merupakan hal yang kompleks karena didalamnya terdapat beberapa tahapan yang sangan rinci mulai dari terampil memahami, mengevaluasi sampai dengan dapat melakukan penalaran dari hasil pemecahan masalah.

\section{METODE PENELITIAN}

Metode penelitian yang digunakan dalam penelitian ini adalah metode eksperimen semu (Quasi Eksperimen). Metode penelitian ini digunakan untuk memprediksi keadaan yang dapat dicapai melalui eksperimen yang sebenarnya, tetapi tidak ada kontrol dan manipulasi terhadap seluruh variabel yang relevan.

Penelitian ini menggunakan desain berbentuk Nonequivalent Control Group Design dengan menggunakan dua kelompok yang terdiri dari kelompok eksperimen dan kelompok kontrol. Perlakuan (Eksperimen) yang diberikan pada penelitian ini adaah model cooperative tipe TGT, sedangkan aspek yang diukur adalah berpikir kritis. Dengan demikian desain penelitian ini dapat dilihat pada Tabel 1

Tabel 1. Desain penelitian

\begin{tabular}{cccc}
\hline Kelompok & $\begin{array}{c}\text { Prete } \\
\mathrm{s}\end{array}$ & $\begin{array}{c}\text { Perlakua } \\
\mathrm{n}\end{array}$ & $\begin{array}{c}\text { Poste } \\
\mathrm{s}\end{array}$ \\
\hline $\begin{array}{c}\text { Eksperime } \\
\mathrm{n}\end{array}$ & $\mathrm{O}_{1}$ & $\mathrm{X}$ & $\mathrm{O}_{2}$ \\
\hline Kontrol & $\mathrm{O}_{3}$ & - & $\mathrm{O}_{4}$ \\
\hline
\end{tabular}


Jurnal KONTEKSTUAL, Volume 1, No. 01, Agustus 2019, pp. 45-53

Keterangan:

$\mathrm{O}_{1}=$ Data hasil pretes kelas eksperimen

$\mathrm{O}_{2}=$ Data hasil postes kelas eksperimen

$\mathrm{O}_{3}=$ Data hasil prestes kelas kontrol

$\mathrm{O}_{4}=$ Data hasil postes kelas kontrol

$\mathrm{X}=$ Perlakuan yang diberikan pada kelas eksperimen menggunakan model cooperative tipe TGT

Populasi dalam penelitian ini adalah siswa kelas IV A dan IV B di SDN 1 Dukuhtengah yang berjumah 60 siswa dengan rincian sebagai berikut:

Sampel yang digunakan dalam penelitian ini adalah sampel jenuh dimana seluruh anggota populasi digunakan sebagai sampel. Sampel yang akan digunkan dalam penelitian ini adalah seluruh siswa kelas IV A yang terdiri dari 30 siswa sebagai kelas eksperimen dan seluruh siswa kelas IV B terdiri dari 30 siswa sebagai kelas kontrol.

Adapun Teknik pengumpulan data yang akan digunakan dalam penelitianini adalah sebagai berikut:

a. Observasi

Teknik pengumpulan data dalam penelitian ini salah satunya adalah observasi dengan jenis observasi terstruktur. Terdapat beberapa yang perlu diobservasi baik kelas eksperimen maupu kelas kontrol yaitu persiapan menagjar, Kondisi kelas, Aktivitas resppon siswa, dan pengelolaan kelas [10].

b. Tes

Pengumpulan data melalui teknik tes mencakup pada indikator kemampuan berpikir kritis antara lain memberikan penjelasan sederhana, membangun keterampilan dasar, menyimpulkan, memberi penjelasan lanjut, serta mengatur strategi dan taktik.

c. Dokumentasi

Pengumpulan data menggunakan teknik dkumentasi ini merupakan analisis dokumen yang diperlukan dalam proses penelitian yaitu hasil belajar baik kelas eksperimen maupun kelas kontrol, kurikulum yang digunakan sekolah, silabus yang digunakan sekolah, dan RPP mata pelajaran matematka yang digunakan kelas eksperimen dan kelas kontrol.

Teknik analisis data yang akan digunakan dalam penelitian ini adalah sebagai berikut:

a. Analisis Statistik Deskriptif

Statistik deskriptif atau statistik deduktif adalah statistik yang mempunyai tugas untuk mengumpulkan, mengolah dan menganalisis data kemudian menyajikannya dengan baik . Penyajian data dalam statistik deskriptif berupa tabel ditribusi frekuensi, histogram, polygon dan diagram ogive[11].

b. Statistik inferensial

Statistik inferensial atau statistik induktif yaitu statistik yang mempunyai tugas mengambil kesimpulan dan membuat keputusan yang baik dan rasional, disamping mengumpulkan data, menyajikan, menganlisis dan menginterpretasikannya. Adapun untuk menganalisis statistik inferensial menggunakan uji normalitas dan uji homogenitas kemudian dilanjutkan dengan uji hipotesis[11].

\section{HASIL DAN PEMBAHASAN}

\section{Hasil}


Jurnal KONTEKSTUAL

Volume 01, No. 1, Agustus 2019, pp. 45-53

Bagian ini melaporkan hasil penelitian yang mencakup hasil analisis prestes dan postes pada penggunaan model cooperative tipe TGT pada proses pembelajaran matematika di kelas IV SDN 1 Dukuhtengah. Tahap awal penelitian melalui studi lapangan, diketahui bahwa model pembelajaran yang digunakan kurang menarik dan cenderung membosankan serta kurang dapat menggali kemampuan berpikir kreatif siswa. Temuan dan hasil literatur model pembelajaran yang cocok untuk menggali kemampuan berpikir kritis siswa adalah model cooperative tipe TGT.

Berdasarkan hasil analisis prestes yang menggunakan uji $\mathrm{t}$ the pooled varians model t-test diperoleh $\mathrm{t}_{\text {hitung }}=$ $1,94 \mathrm{t}_{\text {tabel }}=2,08$ pada taraf signifikan $\alpha$ $=0,05$. Dari hasil perhitungan tersebut diperoleh hasil $t_{\text {hitung }}(1,94)<t_{\text {tabel }}$ $(2,08)$ maka dapat disimpulkan $\mathrm{H}_{\mathrm{o}}$ diterima artinya tdk terdapat pengaruh yang signifikan terhadap kemampuan berpikir kritis siswa yang diberi pembelajaran enggunakan model konensional dengan pembelajaran yang menggunakan model cooperative tipe TGT.

Berdasarkan hasil analisis postes yang menggunakan uji $\mathrm{t}$ the pooled varians model $t$-test diperoleh $t_{\text {hitung }}=$ 2,53 dan $t_{\text {tabel }}=2,08$ pada taraf signifikan $\alpha=0,05$. Dari hasil perhitungan tersebut diperoleh $t_{\text {hitung }}(2,53)>t_{\text {tabel }}(2,08)$ maka dapat disimpulkan $\mathrm{H}_{\mathrm{I}}$ diterima artinya sterdapat pengaruh yang signifikan terhadap kemampuan berpikir kritis siswa yang diberi model cooperative tipe TGT dengan yang diberi model konvensional.

Hasil pengujian hipotesis menggunakan uji-t dapat dilihat pada tabel 2.

Tabel 2
Hasil Uji-t data Pretes dan postes Kelas Eksperimen dan Kelas Kontrol

\begin{tabular}{ccc}
\hline Data & $\begin{array}{c}\text { Nilai } \\
\mathrm{t}_{\text {hitung }}\end{array}$ & Nilai $_{\text {tabel }}$ \\
\hline Pretes & 1,94 & 2,08 \\
\hline Postes & 2,53 & 2,08 \\
\hline
\end{tabular}

Pada hipotesis yang pertama dapat dilihat bahwa tidak terdapat perbedaan yang signifikan kemampuan berpikir kritis antara siswa yang diberi pembelajaran menggunakan model konvensional dengan siswa yang diberikan pembelajaran menggunakan model cooperative tipe TGT. Sedangkan pada hipotesis yang kedua, terdapat perbedaan yang signifikan kemampuan berpikir kritis antara siswa yang diberi pembelajaran menggunakan model konvensional dengan siswa yang diberi pembelajaran menggunakan model cooperative tipe TGT.

\section{Pembahasan}

Pengumpulan data penelitian telah dilaksanakan sesuai dengan rancangan penelitian. Langkah pertama yaitu dengan uji coba instrumen yang bertujuan untuk menguji kualitas instrumen penelitian. Selanjutnya, hasil instrumen yang telah memenuhi standar dapat digunakan untuk mengumpulkan data penelitian. Data mentah yang telah terkumpul kemudian diolah untuk menghasilkan nilai-nilai variabel. Nilai tersebut menjadi objek bagi analisis prasyarat, setelah semua data lolos uji prasyarat kemudian dianalisis.

Penelitian ini bertujuan untuk mengetahui pengaruh model cooperative tipe TGT terhadap kemampuan berpikir kritis siswa kelas IV SDN 1 Dukuhtengah. Dari hasil uji-t yang telah dilakukan mendapatkan hasil Berdasarkan hasil analisis prestes yang menggunakan uji $\mathrm{t}$ the pooled varians model t-test diperoleh 
$t_{\text {hitung }}=1,94 \quad t_{\text {tabel }}=2,08$ pada taraf signifikan $\alpha=0,05$. Dari hasil perhitungan tersebut diperoleh hasil $t_{\text {hitung }}(1,94)<$ $\mathrm{t}_{\text {tabel }}(2,08)$ maka dapat disimpulkan $\mathrm{H}_{\mathrm{o}}$ diterima artinya tdk terdapat pengaruh yang signifikan terhadap kemampuan berpikir kritis siswa yang diberi pembelajaran enggunakan model konensional dengan pembelajaran yang menggunakan model cooperative tipe TGT.

Berdasarkan hasil analisis postes yang menggunakan uji $\mathrm{t}$ the pooled varians model $t$-test diperoleh $t_{\text {hitung }}=$ 2,53 dan $t_{\text {tabel }}=2,08$ pada taraf signifikan $\alpha=0,05$. Dari hasil perhitungan tersebut diperoleh $t_{\text {hitung }}(2,53)>t_{\text {tabel }}(2,08)$ maka dapat disimpulkan $\mathrm{H}_{\mathrm{I}}$ diterima artinya sterdapat pengaruh yang signifikan terhadap kemampuan berpikir kritis siswa yang diberi model cooperative tipe TGT dengan yang diberi model konvensional.

Hal ini diperkuat dengan pendapat peneliti [12] yang menyatakan bahwa model pembelajaran adalah suatu perencanaan atau pola yang digunakan sebagai pedoman dalam merencanakan pembelajaran di dalam kelas dengan mementuka perangkat-perangkat untuk membantu siswa mencapai tujuan pembelajaran yang telah ditetapkan. Sesuai dengan pendapat beberapa ahli terkait model cooperative tipe TGT merupakan suatu model pembelajaran yang berisi turnamen akademik dengan melibatkan aktivitas seluruh siswa yang memiliki kemampuan., jenis kelamin dan suku atau yang yang berbeda.

Diperkuat oleh pendapat penelitian [13] yang menyatakan bahwa karakteristik model cooperative tipe TGT mempunyai lima komponen utama, yaitu; penyajian kelas, kelompok (teams), games, turnamen serta penghargaan kelompok. Model pembelajaran cooperative tipe TGT berpengaruh terhadap kemampuan berpikir kritis siswa, terdapat beberapa faktor yang mempengaruhinya antara lain; a) Model cooperative tipe TGT tidak hanya membuat siswa yang cerdas lebih menonjol dalam pembelajarannya, tetapi siswa yang berkemmapuan lebih rendah juga ikut aktif dan mempunyai peranan penting dalam kelompoknya, b) Menumbuhkan rasa kebersamaan dan saling menghargai sesame anggota kelompok, c) membuat siswa lebih semangat dalam mengikuti peajaran karena dalam pembelajaran ini guru menyajikan sebuah penghargaan pada siswa atau kelompok terbaik, d) Siswa menjadi lebih senang dalam mengikuti pelajaran karena kegiatan permainan berupa turnmen.

\section{KESIMPULAN}

Berdasarkan hasil penelitian terkait dengan pengaruh model cooperative tipe TGT terhadap kemampuan berpikir kritis siswa kelas IV SDN 1 Dukuhtengah karakteristik kevalidan dan keefektifan. Aktivitas siswa dengan model cooperative tipe TGT memungkinkan siswa dapat belajar lebih rileks disamping menumbuhkan tanggung jawab, kerja sama, persaingan sehat dan keterlibatan dalam belajar. Sehingga dalam hal ini benar dikatakan bahwa terdapat pengaruh yang signifikan model pemblajaran cooperative tipe TGT terhadap kemampuan berpikir kritis siswa kelas IV SDN 1 Dukuhtengah.

Berdasarkan hasil uji-t data pretes terdapat perbedaan rata-rata kemampuan berpikir kritis siswa yang pembelajarannya menggunakan cooperative tipe TGT diperoleh $t_{\text {hitung }}=$ 
$1,94 \mathrm{t}_{\text {tabel }}=2,08$ pada taraf signifikan $\alpha$ $=0,05$. Dari hasil perhitungan tersebut diperoleh hasil $t_{\text {hitung }}(1,94)<t_{\text {tabel }}$ $(2,08)$ maka dapat disimpulkan $\mathrm{H}_{\mathrm{o}}$ diterima artinya tdk terdapat pengaruh yang signifikan terhadap kemampuan berpikir kritis siswa yang diberi pembelajaran enggunakan model konensional dengan pembelajaran yang menggunakan model cooperative tipe TGT.

Dari data hasil analisis terdapat peningkatan kemampuan berpikir kritis yang signifikan pada siswa terdapat perbedaan yang signifikan pada saat model pembelajaran cooperative tipe TGT diterapkan di kelas eksperimen, diperoleh hasil $t_{\text {hitung }}=2,53$ dan $t_{\text {tabel }}=2,08$ pada taraf signifikan $\alpha=0,05$. Dari hasil perhitungan tersebut diperoleh $t_{\text {hitung }}$ $(2,53)>t_{\text {tabel }}(2,08)$ maka dapat disimpulkan $\mathrm{H}_{\mathrm{I}}$ diterima artinya terdapat pengaruh yang signifikan terhadap kemampuan berpikir kritis siswa yang diberi model cooperative tipe TGT dengan yang diberi model konvensional.

Kegiatan pembelajaran menggunakan model cooperative tipe TGT membutuhkan lebih dari satu guru di dalam kelas, dikarenakan agar mampu mengontrol kegiatan turnamen siswa. Hal tersebut memeprlukan pengawasan yang ketat terkait materi belajarnya. Pemberian tugas pada masing-masing anggota kelompok harus seimbang agar semua berpusat pada materi yang sedang dipelajari.

\section{DAFTAR PUSTAKA}

[1] Sadulloh, 2011, Belajar dan Pembelajaran. Bandung: Rosada.

[2] Mustaji, 2012, Pengembangan Kemampuan Berpikir Kritis dan
Kreatif dalam

Pembelajaran.Tersedia Online:

http://pasca.tp.ac.id/site/pengembang an-kemampuan-berpikir-kritis-dan-

kreatif-dalam -pembelajaran diakses tanggal 1-09-2019

[3] Joice, B., Weil, M., Calhoun, E., 2009, Models of Teaching: Modelmodel Pengajaran, Yogyakarta: Pustaka Pelajar.

[4] Sharan, S., 2014, The handbook of Cooerative Learning: Inovasi Pengajaran dan Pembelajaran Untuk Mengacu Keberhasilan Siswa di Kelas, Yogyakarta: Istana Media.

[5] Slavin. R.E., 2012, Cooperative Learning, Bandung: Nusa Media

[6] Rusman., 2011, Model-model Pembelajaran, Depok: Rajawali

[7] Nuraeni, Z., 2018, Implementasi Model Cooperative Learning Type Jigsaw Untuk Meningkatkan Partisipasi Belajar Mahasiswa. Theorems, 2 (2)

[8] Sihotang, K. et all., (2012). Critical thinking - Membangun Pemikiran Logis. Jakarta: PT. Pustaka Sinar Harapan.

[9] Chance, P., 1986, Thinking in the Classroom: A Survey of Programs, New York; Teachers Collage, Columbia University.

[10] Creswell, J.W., 2016, Research Design; Pendekatan Metode Kualitatif, Kuantitatif, dan Campuran, Yogyakarta: Pustaka Pelajar

[11] Arifin, Z., 2012, Penelitian Pendidikan- Metode dan Paradigma Baru, Bandung: PT. Remaja Rosdakarya.

[12] Trianto., 2011, Model-model Pembelajaran Inovatif Berorientasi Konstruktivistik, Jakarta: Prestasi Pustaka. 
Jurnal KONTEKSTUAL, Volume 1, No. 01, Agustus 2019, pp. 45-53

[13] Shoimin, A., 2014, 68 Model

Pembelajaran Inovatif dalam

Kurikulum 2013, Yogyakarta: Ar-

Ruzz Media. 